\title{
Sarah Everard \& Nirbhaya: Comparisions and Commonalities
}

Dr Rituparna Bhattacharyya ${ }^{+}$

\section{Abstract}

This brief communication in the form of the editorial attempts to draw out the parallels between two grisly incidents in two parts of the world. The vertiginous ferocity of the incidents jostled outrage across the nations - Sarah Everard's kidnap and murder on 03 March 2021 and barbarity on Nirbhaya through gang-rape and subsequent murder in December 2012. Both the cases unveil an underlying culture of misogyny. The question remains how do we tackle misogyny. Perhaps, deployment of Ubuntu through community engagement is a way forward to magnify respect for women via-à-vis respect for humanity.

Keywords: Sarah Everard; Nirbhaya; Kidnap; Gang-rape; Murder; Misogyny; Ubuntu; United Kingdom; India

\footnotetext{
${ }^{\dagger}$ Editor-in-Chief (joint), Space and Culture, India \& Research Consultant, Email: rituparna.bhattacharyya@accb.org.uk (C) 2021 Bhattacharyya. This is an Open Access article distributed under the terms of the Creative Commons Attribution License (http://creativecommons.org/licenses/by/2.0), which permits unrestricted use, distribution, and reproduction in any medium, provided the original work is properly cited.
} 


\section{Introduction}

The horrific case of Sarah Everard has unleashed a wave of feeling about women not feeling safe at night (Prime Minister, UK, Mr Boris Johnson). ${ }^{1}$

Many women have shared their stories and concerns online since Sarah's disappearance last week. Every woman should feel safe to walk on our streets without fear of harassment or violence (Home Secretary, UK, Priti Patel). ${ }^{2}$

If you're a woman or a girl, your experiences of our city, in any public space, whether it's in the workplace, on the streets, on public transport is very different to if you are a man or a boy....And it's really important that people like me in positions of power and influence understand that and take steps to address that (London Mayor, Mr Sadiq Khan) (Dalton, 2021).

These are some of the powerful statements made by leaders in positions of power in the wake of the kidnap and murder of Sarah Everard, the 33-year-old marketing executive, on 03 March 2021 when she was returning from a friend's house on Leathwaite Road, Clapham, at $9 \mathrm{pm}$ to her Brixton home, which is an approximately 50-minute walk (Ng et al., 2021). This gruesome incident can be compared to the heinous gang-rape of Nirbhaya in a moving bus by six-men on 12 December 2012 (Bhattacharyya, 2015; 2016) when she was returning home with her boyfriend at $9 \mathrm{pm}$ after watching the film Life of Pi in Saket, South Delhi and boarded an off-duty chartered bus at Munirka for Dwarka (Hollingsworth et al., 2020). The bestiality of these incidents undoubtedly shook resentment among the mass (Bhattacharyya, 2015; 2016), leaving a horrid impression on the countries' leadership strategies (Pulla, 2020). Closer scrutiny of both cases unearths a more profound culture of misogyny, which is indeed pervasive across nations.

The ongoing COVID-19 has witnessed an overall escalation of violence against women. Phumzile Mlambo-Ngcuka, Executive Director of UN Women labelled this violence against women and girls as the shadow pandemic. ${ }^{3}$ This editorial is an attempt to make a comparison between the two cases to draw parallels of the same. One might question, are we trying to compare apples with oranges? Not at all. Misogyny in the forms of androcentrism, patriarchal structure, hostility, male privilege, discrimination against sex, social exclusion is a universal phenomenon, which often triggers all forms of violence against women and girls (Lorraine,2000). The following section displays the comparison between the two cases.

\footnotetext{
${ }^{1}$ Government moves to provide reassurance to women and girls: 15 March 2021 (2021,15 March). Press Release, Prime Minister's Office, 10 Downing Street.https://www.gov.uk/government/news/government-moves-to-providereassurance-to-women-and-girls-15-march-2021

${ }^{2}$ Priti Patel@pritipatel-Mar 11 A statement on the Sarah Everard investigation.Twitter. https://twitter.com/pritipatel/status/1369958730209632259

${ }^{3}$ Violence against women and girls: the shadow pandemic

Statement by Phumzile Mlambo-Ngcuka, Executive Director of UN Women (2020, 6 April). UN Women. https://www.unwomen.org/en/news/stories/2020/4/statement-ed-phumzile-violence-against-women-duringpandemic
} 


\section{Comparison between Sarah Everard's and Nirbhaya's case}

Close parallels between the two incidents are painted in the following Table 1.

\begin{tabular}{|c|}
\hline Sarah Everard case \\
\hline $\begin{array}{l}\text { Kidnapped and probably murdered on the } \\
\text { same day, that is on } 03 \text { March } 2021\end{array}$ \\
\hline $\begin{array}{l}\text { Wayne Couzens, a serving Police Officer at } \\
\text { Parliamentary and Diplomatic Protection unit, } \\
\text { Metropolitan Police, UK has been arrested, } \\
\text { charged with kidnapping and murder. }\end{array}$ \\
\hline
\end{tabular}

Wayne Couzens, a highly educated man whose responsibility was to guard the Parliamentary estate (including Downing Street, Westminster Palace and embassies located in London).

Wayne Couzens, himself a keeper of law and a citizen of the world's fifth largest economy, was expected to be highly gender-sensitive.

\section{Nirbhaya case}

On 16 December 2012, Nirbhaya was brutally gang-raped by six men on a moving bus leaving her in a vegetative state. Her boyfriend was physically assaulted too. Nirbhaya later died in a Singapore hospital on 29 December 2012.

Six convicted men included a bus driver-Ram Singh and his associates - Vinay Sharma (fitness trainer and a gym assistant), Akshay Thakur (helper of the bus), Mukesh Singh (brother of Ram Singh who worked as an occasional driver and bus cleaner), Pawan Gupta (a fruit-seller) and a juvenile (cleaner of the bus).

All the six men were mired in multidimensional poverty (with little or no education, low income, the abysmal standard of living in shanties in the Ravi Dass slum).

From the six men's profiles, it is not hard to fathom that they would be ignorant and insensitive to gender issues.

On 16 March 2021, PC Wayne Couzens appeared at the Old Bailey via a video link from Belmarsh prison. His trial begins in October 2021.

Ram Singh committed suicide in Tihar jail on 11 March 2013. The Juvenile Justice Board convicted the juvenile keeping him in a remand home for a maximum term of three years and released him on 18 December 2015. The rest four convicts - Akshay Kumar Singh, Pawan Gupta, Vinay Sharma and Mukesh Singh faced execution at Tihar jail almost a year ago, that is, Friday, the 20 March 2020.

Sources: BBC News (2020a; 2020b); Dodd (2021); Hollingsworth et al. (2020); Ellis-Petersen (2020); Ng et al. (2021)

In the aftermath of the Sarah Everard incident, the UK Government has decided to augment women and girls' safety in public and private

${ }^{4}$ Police, Crime, Sentencing and Courts Bill. https://publications.parliament.uk/pa/bills/cbill/5801/0268/200268.pdf spaces by heightening stringency through amendments of the existing legislations - Police Crime and Sentencing Bill ${ }^{4,5}$ and Domestic Abuse

${ }^{5}$ However, on 21 March 2021, violent protests erupted in the Bristol city of the UK for bestowing more powers to 
Bill. ${ }^{6}$ The Government has doubled the 'Safer Street Fund' to about $£ 45$ million to increase street lighting, CCTVs (including alleyways, parks, routes from nightclubs, bars, and restaurants) to reclaim street confidence. Besides, the Government aims to roll out Project Vigilant across the country to amplify police patrolling (both in uniformed and civil outfits) to identify suspicious and predatory offenders. ${ }^{7}$ Similarly, post Nirbhaya incident, the Government of India has amended and enacted legislations-Criminal Law (Amendment) Act, $2013{ }^{8}$ and Juvenile Justice (Care and Protection of Children) Act 2015, 9,10 The Protection of Children from Sexual Offences (Amendment) Act, 2019. ${ }^{11}$ Yet, violence against women and girls continues to be unbridled- Nagaon, Kathua, Jharkhand, Guntur, and Hathras (Apparasu, 2018; Bhattacharyya and Prasad, 2020; Eltagouri, 2018). ${ }^{12,13}$ In the UK too, violence against women and girls and hate-crime is widespread.

As a result of the rampant rise of violence against women and girls, in October 2020, a 14-year-old led a group of 100 girls and applied for permission to seek licences at Rajkot Collector's office, Gujarat, to use firearms as a measure of self-defence when out in public. ${ }^{14}$ In 1990, Umoja Uaso- an all-female matriarchal village was established in northern Kenya under Rebecca Lolosoli's leadership, a Samburu woman herself, and 15 female victims of rape (perpetrated by local British soldiers) where men are literally banned. This village is located near

the police force (for details, please see, Cascian, 2021; Mullany, 2021).

${ }^{6}$ Domestic Abuse Bill.

https://bills.parliament.uk/Publications/40951/Documen ts/92/5801184.pdf

${ }^{7}$ Please refer to footnote 1

${ }^{8}$ The Criminal Law (Amendment) Act, 2013, The Gazette of India. No 13 of

2013.https://www.iitk.ac.in/wc/data/TheCriminalLaw.pdf

${ }^{9}$ Juvenile Justice (Care and Protection of Children) Act, 2015, Ministry of Women \& Child Development, Government of India. https://wcd.nic.in/acts/juvenilejustice-care-and-protection-children-act-2015

10 This act was amended to try adolescents under the age of 18 and between 14 to 17 years as adults should they commit ghastly and horrid crimes under the Indian Penal Code.
Archers Post's town in Samburu County, $240 \mathrm{mi}$ (380 km) from Kenya's capital, Nairobi (Bindel, 2015; Maitra, 2020). This village serves as a haven for all female victims of Samburu who have survived violence, including forced marriage, domestic violence and female genital mutilations (Bindel, 2015; Maitra, 2020). As of 2015, there were 47 women and 200 children in the village (Bindel, 2015; Maitra, 2020). Arguably, these are some of the collateral consequences of misogyny promoting misandry. The question that emerges is how do we champion for structural change to tackle misogyny and achieve egalitarianism? Is it even possible? Perhaps, the philosophy of Ubuntu has the answer.

\section{Ubuntu}

On 18 March 2021, World Social Work Day at the United Nations was celebrated using the concept of Ubuntu, meaning "I am because we are", or "humanity towards others" marking that the notion is embedded in humanity (Desmond, 2013). The word Ubuntu originates in the Zulu and Xhosa languages rooted in Afrocentric philosophy. According to Archbishop Desmond Tutu:

A person with ubuntu is open and available to others, affirming of others, does not feel threatened that others are able and good, for he or she has a proper self-assurance that comes from knowing that he or she belongs in a greater whole and is diminished when others are

${ }^{11}$ The Protection of Children from Sexual Offences

(Amendment) Act, 2019. Ministry of Law and Justice. The Gazette of India.

https://wcd.nic.in/sites/default/files/Protection\%20of\%2 OChildren\%20From\%20Sexual\%200ffences\%20\%28Amen dment\%29\%20Act\%2C\%202019.pdf

12 India girl, 16, burnt alive after Jharkhand rape (2018, 5 May). BBC News. http://www.bbc.co.uk/news/worldasia-india-44016176

${ }^{13}$ Hathras case: A woman repeatedly reported rape. Why are police denying it? (2020, 10 October). BBC News. https://www.bbc.co.uk/news/world-asia-india-54444939 ${ }^{14}$ Gujarat: 100 girls led by 14 -year-old seek licence to use firearms in self defence (2020, 13 October).India Today. https://www.indiatoday.in/india/story/gujarat-100-girlsled-by-14-year-old-seek-licence-to-use-firearms-in-selfdefence-1731162-2020-10-13 
humiliated or diminished, when others are tortured or oppressed. ${ }^{15}$

Ubuntu reminds us of the quintessence of being human respecting diversity and humanity while embracing equality and equity (for the explanation of equality and equity, please read Pulla et al., 2020). Ubuntu propounds that it is the collective responsibility of a community to raise a child. Sewpaul (2021) argues that "[u]buntu means challenging and undoing structural sources of privilege and power, and of disadvantage, violence, exclusion and oppression." Ergo, to cultivate respect for women by tackling misogyny and bestow humanity across all forms of gender and build a safer society (Pulla, 2020 a; b; c), there has to be a massive change in the curriculum since preschool- teaching children that mutual respect and rationality are human values' ethea (Pulla, 2020a; b; c).

\section{References}

Apparasu, Srinivasa Rao (2018, 04 May). 60year-old Guntur man, accused of raping nineyear-old girl, found hanging. Hindusthan Times. https://tinyurl.com/59yn6kvv

BBC News (2020a, 20 March). Nirbhaya case: Four Indian men executed for 2012 Delhi bus rape and murder.https://www.bbc.co.uk/news/worldasia-india-51969961

BBC News (2020b, 20 March). Profiles: Who were the Delhi gang rape convicts?. https://www.bbc.co.uk/news/world-asia-india23434888

Bindel, Julie (2015, 16 August). The village where men are banned. The Guardian. https://tinyurl.com/ynzteu77

Bhattacharyya, R. and Prasad Sanjay (2020). Chapter 15: Geographies of Indian Women's Everyday Public Safety. In Rajiv Thakur, Ashok Dutt, Sudhir Thakur, George Pomeroy (eds.).Urban and Regional Planning and Development: 20th Century Forms and 21st
Century Transformations, Springer, Cham, DOI https://doi.org/10.1007/978-3-030-31776-8_15

Bhattacharyya, Rituparna (2016). Street

Violence against Indian Women in India:

Mapping Prevention Strategies, Asian Social

Work and Policy Review, 10 (3), 311-325, DOI:

10.1111/aswp.12099

Bhattacharyya, Rituparna (2015).

Understanding the Spatialities of Sexual Assault against Indian women in India, Journal Gender,

Place and Culture: A Journal of Feminist

Geography, 22(9), 1340-1356

DOI:10.1080/0966369X.2014.969684

Casciani, Dominic (2021,16 March). What is the Police, Crime, Sentencing and Courts Bill and how will it change protests? BBC News. https://www.bbc.co.uk/news/uk-56400751

Dalton, Jane (2021, 11 March). London streets not safe for women or girls, admits Sadiq Khan. Independent. https://tinyurl.com/r3ae4rss

Desmond, Tutu (2013).Who we are: Human uniqueness and the African spirit of Ubuntu. YouTube.

https://www.youtube.com/watch?v=ftjdDOfTzb k

Dodd,Vikram (2021,16 March). Wayne Couzens to go on trial in autumn accused of murdering Sarah Everard. The Guardian. https://tinyurl.com/ykfx3rtd

Ellis-Petersen, Hannah (2020, 20 March). India executes four men convicted of 2012 Delhi bus rape and murder. The Guardian.

https://tinyurl.com/yxz6np97

Eltagouri, Marwa (2018, 11 April). An 8-yearold's rape and murder inflames tensions between Hindus and Muslims in India. The Washington Post. https://tinyurl.com/54455m8r Hollingsworth, Julia, Gupta, Swati and Suri, Manveena (2020, 20 March). 7 years after bus rape and murder shocked the world, attackers hanged in New Delhi. CNN. https://tinyurl.com/4m3x2xpy

elp.ubuntu.com/10.04/about-ubuntu/C/about-ubuntuname.html 
Lorraine, Code(2000). Encyclopaedia of Feminist Theories (1st ed.). London: Routledge.

Maitra, Labanya (2020,16 November). Did You Know About This Village Where Men Are Banned? Some might argue they have the right idea, let's explore it first. Outlook Traveller. https://tinyurl.com/3yvz44we

Mullany, Gerry (2021, 21 March). U.K. Police Bill Protesters Turn Violent at Bristol Rally. The New York Times.

https://www.nytimes.com/2021/03/21/world/e urope/uk-police-bill-bristol-protest.html

$\mathrm{Ng}$, Kate, Hancock, Sam, and Osborne, Samuel (2021, 18 March). Sarah Everard disappearance: What we know so far. Independent. https://tinyurl.com/pkk5b8s

Pulla, Venkat, Carter, Elizabeth, and Bhattacharyya, Rituparna (2020). Recognising, Understanding and Responding to Racism in India. In Pulla, Venkat Rao., Bhattacharyya Rituparna, \& Bhatt Sanjai (2020). Discrimination, Challenge and Response: People of North East India, Palgrave Macmillan, DOI: 10.1007/978-3-030-46251-2_10, 177-195

Pulla, Venkat (2020a, 03 October). Mass

Upliftment Mechanisms _ Vaibhav India 2020 Dr Venkat Pulla Australia. YouTube. https://www.youtube.com/watch?v=EyUObk6s x9w

Pulla, Venkat (2020b, 19 August). The Intersections of Domestic Violence and Child Protection. YouTube.

https://www.youtube.com/watch?v=xOLaeNEt ZSY

Pulla, Venkat (2020c). SWK316 Domestic and Family Violence Week 1 Pulla V 2020. You Tube. https://www.youtube.com/watch?v=JsblcawEY $2 \mathrm{E}$

Sewpaul, Vishanthie (2021, 16 March). United Nations WSWD. Association for Schools of Social Work in Africa. https://m.facebook.com/pg/ASSWA2020/posts /?ref=page_internal\&mt_nav $=0$ 